\title{
Pseudocholinesterase and serum lipoproteins
}

\section{Dear Editors,}

Although the physiological function of serum pseudocholinesterase (PChE) is still obscure, there is some evidence that this enzyme is involved in serum lipoprotein metabolism [1]. In various types of dyslipoproteinemic patients elevated group mean levels of low density lipoprotein (LDL)cholesterol and low levels of high density lipoprotein (HDL)-cholesterol have been found to be associated with high group mean activities of PChE $[2,3]$. It has been suggested that serum PChE activity is positively $[1,3]$ and negatively [3] correlated with LDL and HDL levels, respectively. There is no absolute proof that these proposed relationships are causative in nature. However, studies carried out with laboratory animals have provided some support. The organophosphate compound, phospholine iodide, caused decreased LDL levels and PChE activities in guinea pigs [4]. Similarly, dichlorvos induced an increment of HDL cholesterol, a decrease of LDL cholesterol and a decrease of PChE activity in the serum of rabbits [5]. In rats, disulphiram treatment has been shown to lower both PChE activity and serum total cholesterol [6], which essentially represents HDL cholesterol.

In the course of a study with hypercholesterolemic patients on the cholesterolemic effect of MK-733, a competitive inhibitor of 3-hydroxy-3methylglutaryl coenzyme A reductase [7], we have also measured $\mathrm{PChE}$ activity in serum. This offered the possibility to test whether serum LDL and HDL cholesterol and PChE activity simultaneously shift in directions in humans which would be anticipated on the basis of the observations described above. Eleven patients with heterozygous hypercholesterolemia participated in a multicentre dose-finding study of MK-733 [7]. Our patients received placebo $(n=2)$ or MK-733 $(n=$ 9) at a dose between 2.5 and $80 \mathrm{mg} /$ day for 4 weeks. Thereafter the patients $(n=10)$ were en- rolled in a long-term efficacy study in which MK733 was given in a dose of $20 \mathrm{mg} /$ day during the first 8 weeks and $40 \mathrm{mg} /$ day during a subsequent period of 16 weeks. One patient did not enter the long-term efficacy study for personal reasons. Between the end of the dose-finding study and the start of the long-term efficacy study 4 weeks elapsed during which the patients did not receive lipid lowering therapy. Serum LDL and HDL cholesterol [7] and PChE activity [8] were determined as described.

The data presented in Table 1 show that MK733 lowered LDL cholesterol and increased HDL cholesterol, but did not influence PChE activity. Thus it appears that in heterozygous familial hypercholesterolemic patients PChE activity is not related to changes in LDL and HDL cholesterol, which does not lend support to the idea [1-6] that this esterase is involved in lipoprotein metabolism.

\section{TABLE 1}

EFFECT OF MK-733 ON LDL- AND HDL-CHOLESTEROL AND PChE ACTIVITY IN FAMILIAL HETEROZYGOUS HYPERCHOLESTEROLEMIC PATIENTS

Treatment dose of MK-733: wk-2 to 0 and wk 4-8: no treatment; wk 0-4: between 2.5 and $80 \mathrm{mg} /$ day; wk 8-16: 20 $\mathrm{mg} /$ day; wk 16-32:40 mg/day. Results, expressed as means $\pm \mathrm{SD}$; number of subjects is indicated in parentheses.

\begin{tabular}{clll}
\hline $\begin{array}{l}\text { Time } \\
\text { (weeks) }\end{array}$ & $\begin{array}{l}\text { LDL cholesterol } \\
(\mathrm{mmol} / \mathrm{l})\end{array}$ & $\begin{array}{l}\text { HDL cho- } \\
\text { lesterol } \\
(\mathrm{mmol} / 1)\end{array}$ & $\begin{array}{l}\text { PChE activity } \\
(\mathrm{U} / \mathrm{l})\end{array}$ \\
\hline-2 & $9.26 \pm 2.08(10)$ & $0.99 \pm 0.12$ & $5620 \pm 1160$ \\
0 & $9.17 \pm 2.03(10)$ & $1.03 \pm 0.13$ & $5740 \pm 1292$ \\
1 & $7.68 \pm 2.09(8)$ & $1.03 \pm 0.15$ & $5493 \pm 1371$ \\
2 & $7.23 \pm 1.81(8)$ & $1.01 \pm 0.14$ & $5830 \pm 1690$ \\
4 & $6.32 \pm 1.83(8)$ & $1.03 \pm 0.16$ & $5600 \pm 1254$ \\
8 & $8.22 \pm 1.20(10)$ & $0.99 \pm 0.15$ & $5325 \pm 1312$ \\
16 & $5.74 \pm 1.33(10)$ & $1.09 \pm 0.13$ & $5444 \pm 1300$ \\
32 & $5.48 \pm 1.47(10)$ & $1.11 \pm 0.14$ & $5595 \pm 1107$ \\
\hline
\end{tabular}


The observed simultaneous changes in lipoprotein cholesterol and PChE activity in experimental animals after administration of toxic compounds [4-6] may be fortuitous.

\section{References}

1 Kutty, K.M., Biological function of cholinesterase, Clin. Biochem., 13 (1980) 239.

2 Jain, R., Kutty, K.M., Huang, S.-N. and Kean, K., Pseudocholinesterase/high density lipoprotein cholesterol ratio in serum of normal persons and of hyperlipoproteinemics, Clin. Chem., 29 (1983) 1031.

3 Lehtonen, A., Marniemi, J., Inberg, M., Maatela, J., Alanen, E. and Niittymäki, K., Levels of serum lipids, apolipoproteins A-I and B and pseudocholinesterase activity and their discriminative values in patients with coronary by-pass operation, Atherosclerosis, 59 (1986) 215.

\footnotetext{
${ }^{1}$ Departments of Internal Medicine, and ${ }^{2}$ Clinical Chemistry, Free University Hospital, De Boelelaan 1117, 1081 MB Amsterdam, and ${ }^{3}$ Deparment of Laboratory Animal Science, State University, P.O. Box 80 166, 3508 TD Utrecht (The Netherlands)
}

(Received 13 March, 1987)

(Accepted 27 April, 1987)
4 Kutty, K.M., Jacob, J.C., Hutton, C.J., Davis, P.J. and Peterson, S.C., Serum beta lipoprotein: Studies in a patient and in guinea pigs after the ingestion of organophosphorus compounds, Clin. Biochem., 8 (1975) 379.

5 Ryhänen, R., Herranen, J., Korhonen, K., Penttilä, I., Polvilampi, M. and Puhakainen, E., Relationship between serum lipids, lipoproteins and pseudocholinesterase during organophosphate poisoning in rabbits, Int. J. Biochem., 16 (1984) 687

6 Nousianen, U. and Ryhänen, R., Serum lipids and hepatic microsomal enzymes with special reference to serum cholinesterase in Wistar rats, Gen. Pharmac., 15 (1984) 123.

7 Mol, M.J.T.M., Erkelens, D.W., Gevers Leuven, J.A., Schouten, J.A. and Stalenhoef, A.F.H., Effects of synvinolin (MK-733) on plasma lipids in familial hypercholesterolaemia, Lancet, 2 (1986) 936.

$8 \mathrm{Knedel,} \mathrm{M}$. und Böttger, R., Eine kinetische Methode zur Bestimmung der Aktivität der Pseudocholinesterase (acylcholine acylhydrolase, 3.1.1.8), Klin. Wschr., 45 (1967) 325.

J.A. Schouten ${ }^{1}$
C. Mulder ${ }^{2}$,
A.C. Beynen $^{3}$ 